\title{
Ortaokul Öğrencilerinin Din Kavramına İlişkin Algılarının Metaforlar Aracılığıyla Belirlenmesi
}

\section{The Determination of Secondary School Pupils' Perception of Religion as a Concept via Metaphors}

\author{
Ramazan YILDIRIM*
}

Received: 18 February 2017

\author{
Ahmet Ali GAZEL ${ }^{* *}$
}

\begin{abstract}
Concepts are building blocks of curriculum. Social studies course has a curriculum reflecting subjects like history, geography, economics, anthropology, psychology, philosophy, politics, law and citizenship, and it has a rich content in terms of concepts. In this study, we tried to determine the perception of secondary school pupils about one of these concepts, concept of religion, through metaphors. The study was structured with the phenomenological design which is one of the qualitative designs. The study group was 235 pupils attending $6^{\text {th }}$ and $7^{\text {th }}$ grades in secondary schools in Kütahya central and Altıntaş district in 2015-2016 academic years. The data were collected by means of a form consisting a sentence: "Religion is like ........ because ........". The content analysis method was used to analyze and interpret on data. Totally 112 different metaphors related to religion were uttered by pupils. The most uttered metaphors were light, moon, sun, star and road metaphors. After the content analysis, the metaphors were grouped under different categories and organized in these topics: a guiding, counselling foundation (\%46.37); a protective, saver foundation (\%9.79); an educative, instructive foundation (\%8.09); a necessary foundation (\%6.38); a precious foundation $(\% 5.11)$; a limitless, infinite foundation $(\% 5.11)$; a reflective, rewarding foundation $(\% 5.11)$; a connecting foundation (\%4.68); a purifying foundation (\%3.83); a developing foundation (\%2.98) and a formal foundation (\%2.55). The results suggested that pupils' perceptions of religion were positive regarding the categories and the uttered metaphors.
\end{abstract}

Keywords: social studies, concept, religion, metaphor, perception.

ÖZ: Kavramlar öğretim programlarının yapı taşlarındandır. Tarih, coğrafya, ekonomi, antropoloji, psikoloji, felsefe, siyaset bilimi, hukuk ve vatandaşlık bilgisi konularını yansıtan bir öğretim programına sahip olan Sosyal Bilgiler dersi, kavramlar bakımından oldukça zengin bir içeriğe sahiptir. $\mathrm{Bu}$ araştırmada, ortaokul öğrencilerinin bu kavramlardan birisi olan din kavramına ilişkin algıları metaforlar aracılığıyla belirlenmeye çalışılmıştır. Araştırma nitel araştırma desenlerinden olgubilim (fenomenoloji) desenine göre yapılandırılmıştır. Araştırmanın çalışma grubunu 2015-2016 eğitim öğretim yılında Kütahya Merkez ve Altıntaş ilçelerindeki ortaokulların 6. ve 7. sınıflarında öğrenim gören 235 öğrenci oluşturmuştur. Araştırma verileri, “Din ... gibidir; çünkü ...” cümlesini içeren bir form aracılığıyla toplanmıştır. Verilerin analizi ve yorumlanmasında içerik analizi tekniği kullanılmıştır. Öğrenciler tarafından din kavramına ilişkin olarak toplam 112 farklı metafor üretilmiştir. Üretilen metaforlar içerisinde en fazla tercih edilen metaforlar 1şık, ay, güneş, yıldız ve yol metaforları olmuştur. İçerik analizi sonrası metaforlar 11 farklı kategori altında toplanmıştır. Bu kategoriler rehber, yol gösterici bir kurum (\%46.37), koruyucu, kurtarıcı bir kurum (\%9.79), eğiten, öğreten bir kurum (\%8.09), gerekli bir kurum (\%6.38), değerli bir kurum (\%5.11), sınırs1z, sonsuz bir kurum (\%5.11), yansıtan, ödüllendiren bir kurum (\%5.11), birleştiren bir kurum (\%4.68), arındıran bir kurum (\%3.83), gelişen bir kurum (\%2.98) ve kuralları olan bir kurum (\%2.55) şeklinde düzenlenmiştir.

Anahtar kelimeler: sosyal bilgiler, kavram, din, metafor, alg1.

Corresponding Author: Doctoral student, Afyon Kocatepe University, Afyonkarahisar, Turkey, rmznyldrm@gmail.com

Prof. Dr., Afyon Kocatepe University, Afyonkarahisar, Turkey, agazel@aku.edu.tr

Citation Information

Yıldırım, R. \& Gazel, A. A. (2018). Ortaokul öğrencilerinin din kavramına ilişkin algılarının metaforlar aracılığıyla belirlenmesi. Kuramsal Eğitimbilim Dergisi [Journal of Theoretical Educational Science], 11(1), 30-57. 


\section{Giriş}

Kavram, bir nesnenin veya düşüncenin zihindeki soyut ve genel tasarımı olarak tanımlanmaktadır (Türk Dil Kurumu, 2016). Kavramlar insan düşüncesinin temel taşlarıdır. Nesne ya da olayların hem doğrudan hem de dolaylı olarak gözlenebilen özelliklerinden oluşurlar. Zihinsel bir sınıflama oldukları için gerçek dünyada değil, düşüncelerimizde vardır. Gerçek dünyada, ancak kavramları örnekleyen olgular bulunabilir (Candan, 2004). İnsanlar, çocukluktan itibaren kavramları ve onların adlarını (sözcükleri) öğrenmeye başlamakta, onları sınıflandırmakta ve kavramlar arası ilişkileri yani bilgileri keşfetmektedir. Gerçekte bilişsel yapıda var olan kavramlara, yenilerinin eklenmesi, düzenlenmesi ve yeniden yapılandırılması hayat boyu devam eden bir süreçtir. Diğer taraftan kavram öğretimi ise, ilgili kavramın çocuğun zihninde oluşmasını sağlama işidir (Çaycı, 2007). Kavram öğretimini etkileyen pek çok faktör bulunmaktadır. Kavramların yapısı, öğrencilerin gelişim özellikleri, öğrencinin ailesinin sosyoekonomik özellikleri, okul ortamının özellikleri ve imkânları, öğretmen özellikleri bunlar arasındadır (Alkış, 2012, s. 73). Soyut bir içeriğin öğrenilmesi özellikle düşük yaş gruplarında oldukça zordur. $\mathrm{Bu}$ nedenle kavramları bir dereceye kadar somutlaştırma gayretleri olmuştur (MEB, 2005). Bu amaçla kavram öğretiminde anlam çözümleme tabloları, kavram ağları ve kavram haritaları, kavram bulmacaları, kavram karikatürleri, kavramsal değişim metinleri gibi kullanılabilecek teknik ve materyaller geliştirilmiştir (Alkış, 2012; Dündar, 2008).

Kavramlar öğretim programlarının temel yapı taşlarındandır. Nitekim 2017 yılında güncellenen Sosyal Bilgiler öğretim programında, kavram öğretiminin önemi vurgulanmıştır. Programın uygulanmasında kavram öğretiminde sınıflamalar ve farklı kavram öğretimi yaklaşımlarının dikkate alınması, anlam karmaşası, kavram karmaşası ve kavram yanılgılarının giderilmesine yardımcı olunması beklenmektedir (MEB, 2017). Sosyal bilgiler dersinin tarih, coğrafya, ekonomi, sosyoloji, antropoloji, psikoloji, felsefe, siyaset bilimi ve hukuk gibi sosyal bilimleri ve vatandaşlık bilgisi konularını yansıtan disiplinler arası bir program olması, kavramlar açısından oldukça zengin bir yapıya sahip olmasına neden olmuştur.

Sosyal bilgiler programında yer alan kavramlardan biri de din kavramıdır. Dünyanın neredeyse her köşesinde kaynağı bulunan dinler, var olan kültürler kadar çeşitlilik gösterir. Bu durum ve özellikle tanrı, yaşamın amacı, öbür dünya gibi konular ile ilgili olması din kavramının tanımlanmasını güçleştirmektedir (Wilkinson, 2008, s. 14). Kavram olarak aşkın bir varlığa bağlanma ve bu inancın gerektirdiği düşünce ve uygulamaların bütünü şeklinde ifade edilen din, bir inanç, ibadet ve ahlak sistemidir (Keskin, 2004). 19. yüzyıldan itibaren çeşitli alanlarda yaygın kabul gören pozitivist teorilere göre din, tarihte insanlığın geçirdiği tekâmüle paralel tarzda bir tekamül geçirmiş, ruhçuluk ve tabiata tapınma ile iç içe olan mitolojik dönemi, metafiziğe dayalı kavram ve değerler dönemi izlemiştir. Dolayısıyla ruhçuluk, atalar kültü ve büyü, geleneksel tanrı ve din düşüncesinin temelinde bulunmaktadır; tanrı inancında ise çok tanrıcılıktan tek tanrıcılığa doğru bir değişim söz konusudur (Gündüz, 2010, s. 20). Bu görüşün aksine dinin başlangıcının insanlık tarihi kadar eskiye dayandığını ifade eden görüşler de bulunmaktadır. Yunan tarihçisi Mestrius Plutarchus’un "Dünyayı geziniz, dolaşınız; medeniyetsiz, edebiyatsız, duvarsız insan topluluğu görebilirsiniz ama mabetsiz ve mabutsuz insan topluluğu göremezsiniz" sözü bu görüşü desteklemektedir (Güven, 2012). Din, tarihin her döneminde bireyleri, toplumları ve kurumları etkileyen 
önemli olgulardan biri olmuş; insanın bilinç dünyası ve davranışlarına olduğu kadar ortaya koyduğu eserlerine, sanata, hukuka ve devlete bakışına yansımıştır (Ünsal, 2013, s. 12). Mesela insanların yaptığı ilk büyük binalar mabetler olmuş, şehirler mabetlerin etrafında kurulmuş veya ona göre şekillenmiştir. Her dinin icabına göre yapılan mabetler o milletin genellikle en büyük sanat ve mimari eserleri arasında yer almıştır. Dini törenler mimarlık, müzik, dans ve şiir gibi birçok sanat dallarının ortaya çıkmasına yol açmış veya bunların gelişip zenginleşmesine yardım etmiştir (Solmaz, 1996).

Sosyal Bilgiler öğretim programında özellikle tarih odaklı "kültür ve miras" öğrenme alanı içerisinde yer alan bazı kazanımlarda ve değerlerin öğretiminde din olgusuna vurgu yapılması gerekmektedir. Örneğin gaza ve cihat anlayışı, cami ve medrese gibi milli kültürü yansıtan ögelerin tanımlanması, Türk-İslam bilginlerinin dünya bilim mirasına verdiği katkılar din olgusuna vurgu yapılarak öğretilirse, öğrenmeler daha anlamlı hale gelecektir. Öğrencilerin din kavramını nasıl algıladıklarının tespit edilmesi, Sosyal Bilgiler derslerinde öğretmenlerin din olgusuna yapacakları atıflarda yol gösterici olacaktır. Kapsamının geniş olması nedeniyle din, tanımlanması kadar öğretime konu edilmesi de oldukça incelik isteyen bir kavramdır. Kavramların soyut yönlerinin daha iyi anlaşılabilmesi için kavramın olabildiğince somutlaştırılması gerekmektedir. $\mathrm{Bu}$ aşamada metaforlar kavramların somutlaştırılmasına katkıda bulunabilir.

Metafor; farklı kaynaklarda ve bilim alanlarında farklı terimlerle karşılanmaktadır. Sosyoloji ve Felsefede analoji, Edebiyat ve Dilbilim alanında mecaz, ödünçleme, istiare, Eğitimbilim alanında ise daha çok benzetme anlamında kullanılmaktadır (Yapıc1 \& Kösterelioğlu, 2016). Metafor, bir kavramı, olguyu, kendinden daha öteye taşımak, kendinden daha fazlasını yüklemek anlamındaki Yunanca "Metapherein (meta: öte, üst; pherein: taşımak)" kelimesinden türetilmiştir (Uyan-Dur, 2016). Başka bir ifadeyle metafor; bir kavramı, kelimeyi, terimi, olguyu daha güzel ve iyi anlatmak amacıyla, başka bir anlamda olan bir sözcükle, ilgi kurularak benzetme yoluyla kullanılmasıdır (Aydın İ. H., 2006). Metafor herkesçe anlaşılmayan, olağandışı, soyut, alışılmışın dışında olan ve yüksek derecede kurgusal şeylerin keşfedilmesinde ve anlaşılmasında kullanılır. Genel bir kural olarak anlaşılmaya çalışılan şey ne kadar soyut ve kurgusalsa onu anlayabilmek için ihtiyaç duyulan metaforların çeşitliliği de o kadar fazladır (Yob, 2003). Forceville (2002) herhangi bir şeyin metafor olarak etiketlenmesi için metaforu oluşturan terimlerin hangileri olduğunun, bu terimlerin hangisinin hedef alanı hangisinin kaynak alanı temsil ettiğinin, kaynak alandaki hangi özeliklerin hedef alan ile eşleştirildiğinin ve bu özelliklerin seçimine nasıl karar verildiğinin bilinmesi gerektiğini belirtmiştir.

Metafor, bilinmeyen şeylerin öğretilmesi, öğrenilen bilgilerin akılda tutulması ve hatırlanması konusunda geçerliliği kanıtlanmış bir araçtır. Metafor ile öğrenciler yeni bilgileri, zihinlerinde zaten var olan şemaya yapıştırarak eski bilgilerine bağlarlar (Arslan \& Bayrakc1, 2006).

Metaforik düşünme süreci çeşitli aşamalardan meydana gelmektedir. Bu süreç Sezer (2003) tarafından şöyle ifade edilmiştir (aktaran, Eraslan, 2011):

(1) Açıklanmak ya da anlamlandırılmak istenen soyut/somut bir olgu (durum, olay, kavram) 
(2) Bu olguyu açıklamak için kullandığımız somut (belirgin) bir olgu ve bu olgunun dilsel ifadesi

(3) Bu iki olgu arasında kurulan (kurgulanan) özel denklikler ( benzeşmeler)

Ritchie (2013, s. 25) açıklanmak istenen soyut olgu (konu) ile onu açıklamak için kullanılan somut olgu (araç) arasındaki ilişkilendirmede ve metaforun anlaşılmasında üç farklı yaklaşımın olduğunu belirtmektedir. Bu yaklaşımlar yerine koyma, karşılaştırma ve nitelik atfetme yaklaşımlarıdır. Yerine koyma yaklaşımında araç kavram basitçe, hem araca hem de konuya ilişkin bir niteliği gösteren başka bir kavram yerine kullanılmaktadır. Örneğin "Aşil bir aslandır” önermesinde araç kavram olan aslan, Aşil ve aslanda ortak özellik olan cesur sıfatı yerine kullanılmıştır. Bu önerme aslında "Aşil cesurdur" ile aynı anlama gelmektedir (Ritchie, 2013, s. 26). Karşılaştırma yaklaşımında araç ile konu ortak oldukları bazı nitelikler bakımından karşılaştırılmaktadır. Yukarıda verilen önermeden hareketle bu yaklaşımda, Aşil ile aslan mertlik veya vahşilik gibi nitelikleri bakımından karşılaştırılmaktadır. Burada önerme "Aşil aslan gibidir" şeklinde düzenlenmektedir. Aşil'in mertliği veya vahşiliği aslana benzemektedir (Ritchie, 2013, s. 37). Nitelik atfetme yaklaşımında ise araç ile ilgili bir ya da daha fazla nitelik konuya atfedilmektedir. Bu yaklaşım konunun ne şekilde araca benzediğini açıklamaya çalışmaktadır. Örnekten yola çıkılırsa aslanda var olan mertlik veya vahşilik nitelikleri Aşil'e atfedilmektedir. Aşil'in hangi yönleriyle aslana benzediği açıklanmaktadır. Bir metafor analizi için bu yaklaşımlardan hangisinin iyi olduğu, cevaplanmak istenen soruya bağlıdır (Ritchie, 2013, s. 37).

Alanyazın incelendiğinde, Sosyal Bilgiler öğretim programında yer alan bazı kavramlarla ilgili metafor çalışmalarının yapıldığı görülmektedir. Bu çalışmalara vatan kavramı (Özkan \& Taşkın, 2014), çevre kavramı (Ateş \& Karatepe, 2013; Aydın F., 2013; Meral, Küçük, \& Gedik, 2016; Yazıc1, 2013), iklim kavramı (Coşkun, 2010), aile kavramı (Baltacı, 2015), teknoloji kavramı (Fidan, 2014; Karaçam \& Aydın, 2014; Korkmaz \& Ünsal, 2016), yardımseverlik kavramı (Sönmez \& Akıncan, 2013) ile ilgili yapılan çalışmalar örnek olarak verilebilir. Bu alanda din kavramıyla ilgili ise herhangi bir metafor çalışmasına rastlanmamıştır. Yapılan çalışma bu anlamda önemli görülmektedir. Çalışmada ortaokul 6. ve 7. sınıf öğrencilerinin din kavramına ilişkin algıları, metaforlar aracılığıyla belirlenmeye çalışılmıştır. Bu kapsamda araştırmanın problemi “Ortaokul 6. ve 7. sınıf öğrencilerinin din kavramına ilişkin metaforik algıları nelerdir ve bu metaforlar hangi kavramsal kategoriler altında toplanmaktadır?" şeklinde belirlenmiştir.

\section{Yöntem}

\section{Araştırmanı Modeli}

$\mathrm{Bu}$ araştırma, nitel araştırma yöntemlerinden olgubilim (fenomenoloji) yaklaşımına göre desenlenmiştir. Olgubilim yaklaşımı, insanların kendilerini ve çevrelerindeki dünyayı nasıl gördüklerini anlamaya odaklanır (Robson, 2015, s. 186). $\mathrm{Bu}$ yaklaşım etkili, duygusal ve sıklıkla yoğun insan deneyimlerini betimlemek için uygundur (Merriam, 2013, s. 26). Bu betimlemeler, söz konusu olgu (fenomen) ile ilgili çeşitli deneyimlere sahip bireylerin deneyimlerinin özüne ulaşılması ile sonuçlanır (Creswell, 2013, s. 14). Yıldırım ve Şimşek'e göre (2013, s. 81) olgubilim araştırmaları, bir olguyu daha iyi tanımamıza ve anlamamıza yardımcı olacak sonuçlar sağlayacak 
örnekler ve yaşantılar ortaya koyabilir. $\mathrm{Bu}$ araştırmada, Sosyal Bilgiler öğretim programında yer alan kavramlardan din kavramının ortaokul öğrencileri tarafından nasıl algılandığını belirlemek amaçlanmış ve bu nedenle olgubilimsel yaklaşım kullanılmıştır.

\section{Katılımcilar}

$\mathrm{Bu}$ araştırma, 2015-2016 eğitim öğretim yılında Kütahya Merkez ve Altıntaş ilçelerindeki ortaokulların 6. ve 7. sınıflarında öğrenim gören toplam 260 öğrencinin katılımıyla gerçekleştirilmiştir. Bu öğrencilerin bazı değişkenlere göre dağılımı Tablo 1 'de gösterilmiştir.

Tablo 1

Çalışma Grubundaki Öğrencilerin Değişkenlere Göre Dă̆ılımı

\begin{tabular}{llll}
\hline Değişkenler & & $f$ & $\%$ \\
\hline \multirow{2}{*}{ İlçe } & Merkez & 106 & 40.77 \\
& Altıntaş & 154 & 59.23 \\
\hline \multirow{3}{*}{ Okul } & Mustafa Kemal Ortaokulu & 86 & 33.08 \\
& Sancaktar İmam Hatip Ortaokulu & 68 & 26.15 \\
& Ergün Çelebi İmam Hatip Ortaokulu & 62 & 23.85 \\
& Fatih Ortaokulu & 44 & 16.92 \\
\multirow{2}{*}{ Okul türü } & Ortaokul & 130 & 50.00 \\
& İmam-Hatip Ortaokulu & 130 & 50.00 \\
\hline
\end{tabular}

Tablo 1'e göre, çalışma grubundaki öğrencilerin 106's1 Merkez ilçede, 154'ü Altıntaş ilçesinde öğrenim görmektedir. Okullara göre dağılıma bakıldığında Mustafa Kemal Ortaokulu'ndan 86 öğrenci, Sancaktar İmam Hatip Ortaokulu'ndan 68 öğrenci, Ergün Çelebi İmam Hatip Ortaokulu'ndan 62 öğrenci ve Fatih Ortaokulu'ndan 44 öğrencinin yer aldığı görülmektedir. Okul türlerine göre dağılımın ise eşit olduğu ve her iki okul türünde de 130 öğrencinin yer aldığı görülmektedir. Çalışmada 260 öğrencinin tamamına din kavramına ilişkin metafor üretmeleri için form dağıtılmıştır. Toplanan formların araştırmacılar tarafından incelenmesi sonucu 25 öğrencinin ürettikleri metaforlar ile metaforun gerekçesi arasında uyumsuzluk olduğu tespit edilmiş ve bu öğrencilerin ürettikleri metaforlar elenerek çalışmanın kapsamı dışında tutulmuştur. $\mathrm{Bu}$ nedenle çalışmanın bulguları 235 öğrenciden elde edilen verilere göre düzenlenmiştir.

\section{Verilerin Toplanması}

Araştırmaya katılan öğrencilerin din kavramını algılamalarına yönelik sahip oldukları metaforları ortaya çıkarmak amacıyla, öğrencilere "Din ... gibidir; çünkü ..." yazılı formlar dağıtılmıştır. Saban, Koçbeker ve Saban'a göre (2006), metafor çalışmalarında gibi kavramı genellikle metafor konusu ile metafor kaynağı arasındaki benzerliği daha net bir şekilde çağrıştırmak için kullanılır. Ayrıca çünkü kavramına da yer verilerek katılımcılardan kendi metaforları için bir gerekçe veya mantıksal dayanak sunmaları istenir. Çalışma başlatılmadan önce öğrencilere metafor kavramı tanımlanmış ve çeşitli örneklerle açıklanmıştır. Ardından öğrencilerden "Din ... gibidir; çünkü ..." 
cümlesini tamamlamaları istenmiştir. Öğrencilere bu çalışma için 25 dakikalık süre verilmiştir. Süre sonunda toplanan formlar analize tabi tutulmuştur.

\section{Verilerin Analizi}

Öğrenciler tarafından üretilen metaforlar; (1) kodlama ve ayıklama, (2) örnek metafor listesi oluşturma, (3) kategori geliştirme, (4) geçerlik ve güvenirliği sağlama, (5) nicel veriye dönüştürme aşamalarından geçirilerek analiz edilmişlerdir (Saban, 2009).

Kodlama ve ayıklama aşamasında, öncelikle öğrencilerin ürettikleri metaforlar alfabetik olarak sıralanmış, ardından üretilen metaforlar ile gerekçeler incelenmiştir. İnceleme sonrasında din kavramıyla ilgili herhangi bir metaforun yer almadığı, üretilen metaforun gerekçelendirilmediği veya metafor ile gerekçe arasında mantıksal bağın kurulamadığı formlar ayıklanarak çalışmanın dışında bırakılmıştır. $\mathrm{Bu}$ şekilde çalışmanın dışında bırakılan form sayısı 25'tir. Ayıklamanın ardından öğrenciler tarafından üretilen metaforlar yol gösterici, değerli, kurallar vb. şekilde basitçe kodlanmıştır.

Örnek metafor listesi oluşturma aşamasında, kodlama ve ayıklama aşamasından sonra elde edilen geçerli metaforlar, alfabetik sıraya konarak tekrar incelenmiştir ve her metaforu temsil eden öğrenci formlarından birer örnek metafor ifadesi seçilmiştir. Böylece, 112 metaforun her biri için onu en iyi temsil ettiği varsayllan örnek metafor listesi oluşturulmuştur.

Kategori belirleme aşamasında, öğrenciler tarafından din kavramına ilişkin üretilen metaforlar, gerekçelerine bakılarak 11 farklı kategoriye ayrılmıştır. Her kategori altındaki metaforlardan, kategoriyi en iyi temsil ettiği varsayılan örnek metafor ifadeleri seçilerek öğrenci formlarından doğrudan alıntılar yapılmıştır.

Toplanan verilerin ayrıntılı olarak rapor edilmesi ve araştırmacının sonuçlara nasıl ulaştığını açıklaması nitel bir araştırmada geçerliliğin önemli ölçütleri arasında yer almaktadır (Yıldırım \& Şimşek, 2013, s. 291). Bu nedenle araştırmanın geçerliliğini sağlamak için verilerin analizi detaylıca açıklanmış ve toplanan veriler bulgular bölümünde ayrıntılı olarak ele alınmıştır. Araştırmanın güvenirliğini sağlamak için, araştırmada oluşturulan kategorilerde yer alan metaforların, söz konusu kategorileri temsil edip etmediğini belirlemek amaciyla uzman görüşüne başvurulmuştur. Araştırmacılar tarafından oluşturulan öğrencilere ait metafor listeleri ve kategorileri içeren listeler bir uzman tarafından incelenmiştir. Daha sonra uzmanın yaptığı eşleştirmeler ile araştırmacıların oluşturduğu kategoriler karşılaştırılmıştır. Karşılaştırmalarda görüş birliği ve görüş ayrılığı sayıları belirlenerek araştırmanın güvenirliği, Miles ve Huberman'ın (1994, s. 64) formülü (Güvenirlik = Görüş Birliği/ [Görüş Birliği + Görüş Ayrılığı]) kullanılarak hesaplanmıştır. Bu araştırmada, \%91 oranında güvenirlik sağlanmıştır.

Geçerlik ve güvenirliğin sağlanmasının ardından din kavramına ilişkin öğrenciler tarafından üretilen metaforlar nicel veri haline dönüştürülmüştür. Her bir kategoriye ait kaç metafor imgesinin yer aldığı ve bunların kaç katılımcı tarafından üretildiğine yönelik frekans ve yüzde değerlerini gösteren tablolar oluşturulmuş, veriler bu tablolardan yararlanılarak yorumlanmıştır. 


\section{Bulgular}

$\mathrm{Bu}$ bölümde din kavramına ilişkin olarak öğrenciler tarafından üretilen metaforlara, bu metaforların ortak özelliklerine göre gruplandırılması sonucu oluşturulmuş kategorilere ve metaforun gerekçesiyle açıkladığı öğrenci ifadelerine yer verilmiştir. Araştırmada elde edilen geçerli metaforların frekans ve yüzdelik değerleri Tablo 2'de verilmiştir.

Tablo 2

Ortaokul Öğrencilerinin Din Kavramını Algılamalarına İlişkin Olarak Ürettikleri Metaforların Frekans ve Yüzdelik Değerleri

\begin{tabular}{|c|c|c|c|c|c|c|c|c|c|c|c|}
\hline Sira & Metafor & $f$ & $\%$ & Sira & Metafor & $f$ & $\%$ & Sira & Metafor & $f$ & $\%$ \\
\hline 1 & Abdest & 1 & 0.43 & 39 & Deniz feneri & 2 & 0.85 & 77 & Kolon & 1 & 0.43 \\
\hline 2 & $\begin{array}{l}\text { Acil } \\
\text { yardım }\end{array}$ & 1 & 0.43 & 40 & Ders & 1 & 0.43 & 78 & Köprü & 1 & 0.43 \\
\hline 3 & Ăgaç & 5 & 2.13 & 41 & Devlet & 1 & 0.43 & 79 & Kuş & 1 & 0.43 \\
\hline 4 & Ahlak & 1 & 0.43 & 42 & Dil & 1 & 0.43 & 80 & $\begin{array}{l}\text { Kutup } \\
\text { yıldızı }\end{array}$ & 4 & 1.70 \\
\hline 5 & Aile & 2 & 0.85 & 43 & Dostluk & 1 & 0.43 & 81 & Lamba & 3 & 1.28 \\
\hline 6 & Akarsu & 1 & 0.43 & 44 & Dövme & 1 & 0.43 & 82 & Miraç & 1 & 0.43 \\
\hline 7 & Ak1llı alet & 1 & 0.43 & 45 & Dünya & 2 & 0.85 & 83 & Navigasyon & 2 & 0.85 \\
\hline 8 & Altın & 1 & 0.43 & 46 & Ev & 2 & 0.85 & 84 & Nefes & 1 & 0.43 \\
\hline 9 & Anahtar & 4 & 1.70 & 47 & Evren & 2 & 0.85 & 85 & Okul & 3 & 1.28 \\
\hline 10 & Anayasa & 1 & 0.43 & 48 & Fener & 2 & 0.85 & 86 & Okyanus & 1 & 0.43 \\
\hline 11 & Anne & 1 & 0.43 & 49 & Fidan & 1 & 0.43 & 87 & Ödev & 3 & 1.28 \\
\hline 12 & Anne baba & 2 & 0.85 & 50 & Google & 1 & 0.43 & 88 & Öğretmen & 5 & 2.13 \\
\hline 13 & Arkadaş & 1 & 0.43 & 51 & Gökyüzü & 1 & 0.43 & 89 & Öğüt & 1 & 0.43 \\
\hline 14 & Asker & 2 & 0.85 & 52 & Gölge & 1 & 0.43 & 90 & Pencere & 1 & 0.43 \\
\hline 15 & Aşk & 3 & 1.28 & 53 & Göz & 1 & 0.43 & 91 & Perde & 1 & 0.43 \\
\hline 16 & Ay & 8 & 3.40 & 54 & Gül & 1 & 0.43 & 92 & Polis & 1 & 0.43 \\
\hline 17 & Ay 1ş1 & 1 & 0.43 & 55 & Güneş & 8 & 3.40 & 93 & Pusula & 5 & 2.13 \\
\hline 18 & Aydınlatıcı & 1 & 0.43 & 56 & Güzel ahlak & 1 & 0.43 & 94 & Rehber & 3 & 1.28 \\
\hline 19 & Aydınlatma & 1 & 0.43 & 57 & Harita & 2 & 0.85 & 95 & Sevda & 1 & 0.43 \\
\hline 20 & Aydınlık & 2 & 0.85 & 58 & Hayat & 3 & 1.28 & 96 & Silah & 1 & 0.43 \\
\hline 21 & $\begin{array}{l}\text { Aydınlık } \\
\text { bir yol }\end{array}$ & 1 & 0.43 & 59 & Hazine & 1 & 0.43 & 97 & Sopa & 1 & 0.43 \\
\hline 22 & Ayna & 3 & 1.28 & 60 & Hizlı tren & 1 & 0.43 & 98 & $\mathrm{Su}$ & 5 & 2.13 \\
\hline 23 & Babam & 2 & 0.85 & 61 & Iş1k & 27 & 11.49 & 99 & Şemsiye & 3 & 1.28 \\
\hline 24 & Bebek & 1 & 0.43 & 62 & İlim & 1 & 0.43 & 100 & Teknoloji & 1 & 0.43 \\
\hline 25 & Beyaz 1şık & 1 & 0.43 & 63 & İnsan & 1 & 0.43 & 101 & Tohum & 1 & 0.43 \\
\hline 26 & Beyaz örtü & 1 & 0.43 & 64 & İnsan hayatı & 1 & 0.43 & 102 & Uçak & 2 & 0.85 \\
\hline
\end{tabular}




\begin{tabular}{|c|c|c|c|c|c|c|c|c|c|c|c|}
\hline 27 & Bitki & 1 & 0.43 & 65 & İnsan ruhu & 1 & 0.43 & 103 & Vatan & 1 & 0.43 \\
\hline 28 & $\begin{array}{l}\text { Bonkör } \\
\text { insan }\end{array}$ & 1 & 0.43 & 66 & İnternet & 1 & 0.43 & 104 & $\begin{array}{l}\text { Vücut } \\
\text { organı }\end{array}$ & 1 & 0.43 \\
\hline 29 & Boya & 1 & 0.43 & 67 & İskelet & 1 & 0.43 & 105 & Yağmur & 1 & 0.43 \\
\hline 30 & Can yeleği & 1 & 0.43 & 68 & İyilik kutusu & 1 & 0.43 & 106 & Yaşam & 1 & 0.43 \\
\hline 31 & $\begin{array}{l}\text { Cennet } \\
\text { kapısı }\end{array}$ & 1 & 0.43 & 69 & Kalkan & 5 & 2.13 & 107 & Yild1z & 7 & 2.98 \\
\hline 32 & Cumhuriyet & 2 & 0.85 & 70 & Kalp & 4 & 1.70 & 108 & Yol & 7 & 2.98 \\
\hline 33 & Çatı & 1 & 0.43 & 71 & Kan & 1 & 0.43 & 109 & $\begin{array}{l}\text { Yol } \\
\text { gösterici }\end{array}$ & 4 & 1.70 \\
\hline 34 & Çelik & 1 & 0.43 & 72 & Kap1 & 4 & 1.70 & 110 & Yuva & 1 & 0.43 \\
\hline 35 & Çocuk & 1 & 0.43 & 73 & Kardeş & 1 & 0.43 & 111 & $\begin{array}{l}\text { Yüksek } \\
\text { dağlar }\end{array}$ & 1 & 0.43 \\
\hline 36 & Dağ & 1 & 0.43 & 74 & $\begin{array}{l}\text { Keşfedilmemiş } \\
\text { ada }\end{array}$ & 1 & 0.43 & 112 & Zirve & 1 & 0.43 \\
\hline 37 & Damar & 1 & 0.43 & 75 & Kilavuz & 2 & 0.85 & & & & \\
\hline 38 & Defter & 1 & 0.43 & 76 & Kitap & 6 & 2.55 & & Toplam & 235 & 100.00 \\
\hline
\end{tabular}

Tablo 2'ye göre, din kavramını algılamalarına ilişkin olarak 235 ortaokul öğrencisi tarafından 112 farklı metafor üretilmiştir. Bunlar içerisinde en fazla üretilen metafor $\iota s ̧ ı k$ metaforudur. Işsı metaforu 27 öğrenci tarafından tercih edilmiş ve üretilen metaforların \%11.49'unu oluşturmuştur. Bu metaforu sirasıyla 8 kez üretilen ay (\%3.40) ve güneş (\%3.40) metaforları ve $7 \mathrm{kez}$ üretilen yıldız (\%3.40) ve yol (\%3.40) metaforları takip etmiştir. Öğrencilerin din kavramına algılamalarına ilişkin ürettikleri metaforların kategorileri Tablo 3 'te gösterilmiştir. 
Tablo 3

Ortaokul Öğrencilerinin Din Kavramını Algılamalarına İlişkin Olarak Ürettikleri Metaforlarin Kategorileri

\begin{tabular}{clcc}
\hline Sira & Kategoriler & $\boldsymbol{f}$ & $\boldsymbol{\%}$ \\
\hline 1 & Rehber, yol gösterici bir kurum & 109 & 46.37 \\
2 & Koruyucu, kurtarıcı bir kurum & 23 & 9.79 \\
3 & Eğiten, öğreten bir kurum & 19 & 8.09 \\
4 & Gerekli bir kurum & 15 & 6.38 \\
5 & Değerli bir kurum & 12 & 5.11 \\
6 & Sinırsız, sonsuz bir kurum & 12 & 5.11 \\
7 & Yansıtan, ödüllendiren bir kurum & 12 & 5.11 \\
8 & Birleştiren bir kurum & 11 & 4.68 \\
9 & Arındıran bir kurum & 9 & 3.83 \\
10 & Gelişen bir kurum & 7 & 2.98 \\
11 & Kuralları olan bir kurum & 6 & 2.55 \\
\hline & & $\mathbf{2 3 5}$ & $\mathbf{1 0 0}$ \\
\hline
\end{tabular}

Tablo 3'e göre, ortaokul öğrencilerinin din kavramına ilişkin ürettikleri metaforlar 11 kategori altında toplanmıştır. Bu kategoriler rehber, yol gösterici bir kurum (\%46.37), koruyucu, kurtarıcı bir kurum (\%9.79), eğiten, öğreten bir kurum (\%8.09), gerekli bir kurum (\%6.38), değerli bir kurum (\%5.11), sınırsız, sonsuz bir kurum (\%5.11), yansitan, ödüllendiren bir kurum (\%5.11), birleştiren bir kurum (\%4.68), arındıran bir kurum (\%3.83), gelişen bir kurum (\%2.98) ve kuralları olan bir kurum (\%2.55) şeklinde düzenlenmiştir. Öğrencilerin oluşturduğu metaforlarla ilgili kategoriler incelendiğinde öğrencilerin din kavramını en çok rehber, yol gösterici olarak algıladıkları görülmektedir. 
Tablo 4

Rehber, Yol Gösterici Bir Kurum Olarak Din

\begin{tabular}{|c|c|c|c|c|c|c|c|}
\hline Stra & Metafor & $f$ & $\%$ & Stra & Metafor & $f$ & $\%$ \\
\hline 1 & Işık & 26 & 11.05 & 20 & Uçak & 2 & 0.85 \\
\hline 2 & Ay & 7 & 2.98 & 21 & Ağaç & 1 & 0.43 \\
\hline 3 & Yildiz & 6 & 2.55 & 22 & Ak1llı alet & 1 & 0.43 \\
\hline 4 & Yol & 6 & 2.55 & 23 & Anne & 1 & 0.43 \\
\hline 5 & Pusula & 5 & 2.13 & 24 & Anne-Baba & 1 & 0.43 \\
\hline 6 & Anahtar & 4 & 1.70 & 25 & Ay 1 şığı & 1 & 0.43 \\
\hline 7 & Kap1 & 4 & 1.70 & 26 & Aydınlatıcı & 1 & 0.43 \\
\hline 8 & Kutup yıldızı & 4 & 1.70 & 27 & Aydınlatma & 1 & 0.43 \\
\hline 9 & Yol gösterici & 4 & 1.70 & 28 & Aydınlık bir yol & 1 & 0.43 \\
\hline 10 & Güneş & 3 & 1.28 & 29 & Beyaz 1şık & 1 & 0.43 \\
\hline 11 & Lamba & 3 & 1.28 & 30 & Dağ & 1 & 0.43 \\
\hline 12 & Rehber & 3 & 1.28 & 31 & Google & 1 & 0.43 \\
\hline 13 & Aydınlık & 2 & 0.85 & 32 & Gölge & 1 & 0.43 \\
\hline 14 & Babam & 2 & 0.85 & 33 & Göz & 1 & 0.43 \\
\hline 15 & Deniz feneri & 2 & 0.85 & 34 & Kalp & 1 & 0.43 \\
\hline 16 & Fener & 2 & 0.85 & 35 & Kılavuz & 1 & 0.43 \\
\hline 17 & Harita & 2 & 0.85 & 36 & Köprü & 1 & 0.43 \\
\hline 18 & Kitap & 2 & 0.85 & 37 & Öğretmen & 1 & 0.43 \\
\hline 19 & Navigasyon & 2 & 0.85 & 38 & Pencere & 1 & 0.43 \\
\hline \multicolumn{6}{|c|}{ Toplam } & 109 & 46.37 \\
\hline
\end{tabular}

Rehber, yol gösterici bir kurum olarak din kategorisinde, 109 öğrenci tarafından 38 farklı metafor üretilmiştir (Tablo 4). Bu metaforların araştırmada üretilen toplam geçerli metaforlar içerisindeki oranı \%46.37'dir. Kategoride en fazla tercih edilen metafor, 26 öğrenci tarafından üretilen $\iota s ̧ ı k$ metaforudur. Bu metaforu sırasıyla ay, yıld $ı z$ ve yol metaforları takip etmektedir. $\mathrm{Bu}$ kategoride üretilen metaforların gerekçeleri incelendiğinde, öğrencilerin çoğunlukla dinin insanlara doğru yolu gösteren, iyiliğe yönlendiren yönünün olduğuna vurgu yaptıkları görülmektedir. Aşağıda öğrencilerin bu kategoride ürettikleri metaforlar ve gerekçelerinden örnekler sunulmuştur.

“Din ışık gibidir; çünkü karanlıkta bize doğru yolu gösterir.”,

"Din anne-baba gibidir; çünkü bizi iyiliğe yönlendirir."

"Din ay gibidir; çünkü karanlıkta bile bize doğru yolu gösterir."

"Din deniz feneri gibidir; çünkü insan yolunu onun ışı̆̆ında bulur."

"Din harita gibidir; çünkü bize yol gösterir."

“Din köprü gibidir; çünkü doğru yola götürür, uçuruma veya suya düşürmez.”

"Din kutup yıldızı gibidir; çünkü doğru yolu gösterir."

"Din navigasyon gibidir; çünkü yön gösterir." 
"Din pusula gibidir; çünkü yolunu kaybedene yol gösterir."

"Din yıldı gibidir; çünkü bizlere hep doğru yolu gösterir."

"Din Google gibidir; çünkü aradığımız doğruya götürür."

\section{Tablo 5}

Koruyucu, Kurtarıcı Bir Kurum Olarak Din

\begin{tabular}{cllc}
\hline Sira & Metafor & $f$ & $\%$ \\
\hline 1 & Kalkan & 5 & 2.13 \\
2 & Şemsiye & 3 & 1.28 \\
3 & Asker & 2 & 0.85 \\
4 & Beyaz örtü & 1 & 0.43 \\
5 & Bitki & 1 & 0.43 \\
6 & Can yeleği & 1 & 0.43 \\
7 & Çatı & 1 & 0.43 \\
8 & Çelik yelek & 1 & 0.43 \\
9 & Ev & 1 & 0.43 \\
10 & Güzel ahlak & 1 & 0.43 \\
11 & Kilavuz & 1 & 0.43 \\
12 & Kolon & 1 & 0.43 \\
13 & Perde & 1 & 0.43 \\
14 & Polis & 1 & 0.43 \\
15 & Silah & 1 & 0.43 \\
16 & Sopa & 1 & 0.43 \\
\hline
\end{tabular}

Koruyucu, kurtarıcı bir kurum olarak din kategorisinde 23 öğrenci tarafından 16 farklı metafor üretilmiştir (Tablo 5). Bu metaforların araştırmada üretilen toplam geçerli metaforlar içerisindeki oran $1 \% 9.79$ 'dur. Kategoride en fazla tercih edilen metaforlar sırasıyla kalkan, şemsiye ve asker metaforlarıdır. Öğrencilerin bu kategoride dini insanları kötülüklerden, günahlardan koruyan ve güvende tutan bir kavram olarak algılayarak metaforlar ürettikleri görülmektedir. $\mathrm{Bu}$ kategoride öğrenciler tarafından üretilen metaforlar ve gerekçelerinden bazıları şöyledir: korur."

"Din beyaz örtü gibidir; çünkü onu üstümüze örttüğümüzde bizi her şeyden

"Din bitki gibidir; çünkü nasıl bitkiler fotosentez yaparak bize oksijen verirse din de kötülükten alıkoyar. Faydalıya ulaştırır."

"Din can yeleği gibidir; çünkü denize düştüğünde sarllacağın tek şey odur."

"Din çatı gibidir; çünkü bizi dış etkilere karşı korur."

"Din ev gibidir; çünkü girdin mi güvende olursun."

“Din kalkan gibidir; çünkü kötülüklerden korur." 
“Din kolon gibidir; çünkü kolon olmazsa ev yıkılır.”

"Din şemsiye gibidir; çünkü günahlardan bizi korur."

"Din asker gibidir; çünkü kötülüklerden korur."

Tablo 6

Ĕ̈iten, Ögreten Bir Kurum Olarak Din

\begin{tabular}{clcc}
\hline Sira & Metafor & $f$ & $\%$ \\
\hline 1 & Kitap & 4 & 1.70 \\
2 & Öğretmen & 4 & 1.70 \\
3 & Hayat & 3 & 1.28 \\
4 & Acil yardım & 1 & 0.43 \\
5 & Ahlak & 1 & 0.43 \\
6 & Aile & 1 & 0.43 \\
7 & Defter & 1 & 0.43 \\
8 & Işık & 1 & 0.43 \\
9 & İnternet & 1 & 0.43 \\
10 & Okul & 1 & 0.43 \\
11 & Öğ̈̈t & 1 & 0.43 \\
\hline & & $\mathbf{1 9}$ & $\mathbf{8 . 0 9}$ \\
\hline
\end{tabular}

Eğiten, öğreten bir kurum olarak din kategorisinde 19 öğrenci tarafindan 11 farklı metafor üretilmiştir (Tablo 6). Bu metaforların araştırmada üretilen toplam geçerli metaforlar içerisindeki oranı \%8.09'dur. Kategoride en fazla tercih edilen metaforlar sirasıyla kitap, ögretmen, hayat metaforlarıdır. Öğrencilere göre din, insanlara doğruyu yanlışı öğreten, bilgilendiren, içerisinde her türlü bilginin bulunduğu bir kurumdur. Öğrencilerden bazılarının bu kategoride ürettikleri metaforlar ve gerekçeleri şöyledir:

"Din aile gibidir; çünkü insanlarl terbiye eder."

"Din hayat gibidir; çünkü bize doğruyu ve yanlışı öğretir."

"Din internet gibidir; çünkü aradı̆̆ımız her bilgi mevcuttur."

"Din kitap gibidir; çünkü insanları bilgilendirir."

"Din okul gibidir; çünkü her şeyi ondan öğreniriz."

"Din öğretmen gibidir; çünkü bilmediklerimizi öğretir." 
Tablo 7

Gerekli Bir Kurum Olarak Din

\begin{tabular}{clcc}
\hline Sira & Metafor & $f$ & $\%$ \\
\hline 1 & Su & 3 & 1.28 \\
2 & Güneş & 2 & 0.85 \\
3 & Ağaç & 1 & 0.43 \\
4 & Arkadaş & 1 & 0.43 \\
5 & Damar & 1 & 0.43 \\
6 & Dil & 1 & 0.43 \\
7 & İskelet & 1 & 0.43 \\
8 & Kan & 1 & 0.43 \\
9 & Nefes & 1 & 0.43 \\
10 & Vücut organı & 1 & 0.43 \\
11 & Yağmur & 1 & 0.43 \\
12 & Yaşam & 1 & 0.43 \\
\hline
\end{tabular}

Gerekli bir kurum olarak din kategorisinde 15 öğrenci tarafından 12 farklı metafor üretilmiştir (Tablo 7). Bu metaforların araştırmada üretilen toplam geçerli metaforlar içerisindeki oran $1 \% 6.38$ 'dir. Kategoride en fazla tercih edilen metaforlar $s u$ ve güneş metaforlarıdır. Öğrencilerin ürettikleri metaforların gerekçelerine göre din, insanlar için su gibi, güneş gibi, nefes gibi gereklidir. Hayatın her anında insanlar dine ihtiyaç duyarlar. Öğrencilerin ürettikleri metaforlardan bazıları gerekçeleriyle birlikte aşağıda verilmiştir:

"Din güneş gibidir; çünkü insanın vücudunu ısıtır."

"Din iskelet gibidir; çünkü insan onsuz ayakta duramaz."

"Din kan gibidir; çünkü kan olmadı̆̆ı bölge kangren olur."

"Din nefes gibidir; çünkü onsuz yaşayamayız, hayatımızın her anında kullanirı."

"Din su gibidir; çünkü onsuz yaşayamayız."

"Din vücut organları gibidir; çünkü biri olmazsa yaşayamayız."

"Din yă̆mur gibidir; çünkü yeryüzüne hayat verir." 
Tablo 8

Değerli Bir Kurum Olarak Din

\begin{tabular}{clcc}
\hline Sira & Metafor & $\boldsymbol{f}$ & $\boldsymbol{\%}$ \\
\hline 1 & Kalp & 3 & 1.28 \\
2 & Altın & 1 & 0.43 \\
3 & Anne baba & 1 & 0.43 \\
4 & Bebek & 1 & 0.43 \\
5 & Çocuk & 1 & 0.43 \\
6 & Gül & 1 & 0.43 \\
7 & Hazine & 1 & 0.43 \\
8 & İnsan ruhu & 1 & 0.43 \\
9 & Vatan & 1 & 0.43 \\
10 & Yıldı & 1 & 0.43 \\
\hline
\end{tabular}

Değerli bir kurum olarak din kategorisinde 12 öğrenci tarafından 10 farklı metafor üretilmiştir (Tablo 8). Bu metaforların araştırmada üretilen toplam geçerli metaforlar içerisindeki oranı \%5.11'dir. Kategoride en fazla tercih edilen metafor, üç öğrenci tarafından üretilen kalp metaforudur. Diğer metaforlar ise birer öğrenci tarafından üretilmişlerdir. Öğrencilerin bu kategoride dini, insanlar arasında değer atfedilen çeşitli metaforlarla açıkladıkları görülmektedir. Bu kategoride öğrenciler tarafından üretilen metaforlar ve gerekçelerinden bazıları şöyledir:

"Din altın gibidir; çünkü kaybedersek bulunmaz.”

"Din hazine gibidir; çünkü en değerli şeyleri içinde barındırır."

"Din vatan gibidir; çünkü kıymeti büyüktür."

"Din kalp gibidir; çünkü değerli ve önemlidir."

"Din yıldız gibidir; çünkü onun kadar değerlidir." 
Tablo 9

Sinırsız, Sonsuz Bir Kurum Olarak Din

\begin{tabular}{clcc}
\hline Sira & Metafor & $f$ & $\%$ \\
1 & Aşk & 3 & 1.28 \\
2 & Dövme & 1 & 0.43 \\
3 & Gökyüzü & 1 & 0.43 \\
4 & Güneş & 1 & 0.43 \\
5 & İlim & 1 & 0.43 \\
6 & Keşfedilmemiş ada & 1 & 0.43 \\
7 & Miraç & 1 & 0.43 \\
8 & Okyanus & 1 & 0.43 \\
9 & Yol & 1 & 0.43 \\
10 & Yüksek dağlar & 1 & 0.43 \\
\hline
\end{tabular}

Sınırsız, sonsuz bir kurum olarak din kategorisinde 12 öğrenci tarafından 10 farklı metafor üretilmiştir (Tablo 9). Bu metaforların araştırmada üretilen toplam geçerli metaforlar içerisindeki oranı \%5.11'dir. Kategoride en fazla tercih edilen metafor aşk metaforudur. Bu kategoride öğrenciler dini her yeri kaplayan, sonsuza kadar sürecek bir kavram olarak algılayarak çeşitli metaforlar üretmişlerdir. Öğrencilerden bazılarının bu kategoride ürettikleri metaforlar ve gerekçeleri şöyledir:

"Din ilim gibidir; çünkü ögren ögren bitmez."

"Din keşfedilmemiş ada gibidir; çünkü araştırdıkça güzellikleri ortaya çıkar."

"Din okyanus gibidir; çünkü her yeri kaplar."

"Din gökyüzü gibidir; çünkü sonsuzdur."

“Din güneş gibidir; çünkü sonsuza kadar sönmeyecektir.”

"Din dövme gibidir; çünkü kalıcıdır."

"Din aşk gibidir; çünkü seversin bırakamazsın." 
Tablo 10

Yansitan, Ödüllendiren Bir Kurum Olarak Din

\begin{tabular}{clcc}
\hline Sira & Metafor & $\boldsymbol{f}$ & $\boldsymbol{\%}$ \\
\hline 1 & Ağaç & 2 & 0.85 \\
2 & Ayna & 2 & 0.85 \\
3 & Ödev & 2 & 0.85 \\
4 & Bonkör insan & 1 & 0.43 \\
5 & Cennet kapısı & 1 & 0.43 \\
6 & Ders & 1 & 0.43 \\
7 & Hızlı tren & 1 & 0.43 \\
8 & Teknoloji & 1 & 0.43 \\
9 & Zirve & 1 & 0.43 \\
& $\quad$ Toplam & $\mathbf{1 2}$ & $\mathbf{5 . 1 1}$
\end{tabular}

Yansıtan, ödüllendiren bir kurum olarak din kategorisinde 12 öğrenci tarafından 9 farklı metafor üretilmiştir (Tablo 10). Bu metaforların araştırmada üretilen toplam geçerli metaforlar içerisindeki oranı \%5.11'dir. Kategoride en fazla tercih edilen metaforlar ăgaç, ayna ve ödev metaforlarıdır. Öğrencilere göre din, insanların yapmış oldukları olumlu ya da olumsuz davranışları tekrar kendilerine ödül ya da ceza olarak yansıtan bir sisteme sahiptir. Öğrencilerden bazılarının bu kategoride ürettikleri metaforlar ve gerekçeleri şöyledir:

"Din bonkör insan gibidir; çünkü sen ondan zamanını esirgemezsen o da sevabinı esirgemez."

"Din cennet kapısı gibidir; yaptı̆̆ımız her sevapta kapı az az açılır."

"Din zirve gibidir; çünkü zirveye çıkarken zorluklar yaşarız. Zirvenin sonunda bir sonuca ulaşırı cennet ya da cehenneme.'

"Din ăgaç gibidir; çünkü her iyilikte bir meyve açar."

"Din teknoloji gibidir; çünkü nasıl kullanırsak sonumuz da öyle olur."

"Din ayna gibidir; çünkü her şeyi bize geri yansitır."

"Din hızlı tren gibidir; çünkü sırat köprüsünden hızl geçmemizi să̆lar."

"Din ödev gibidir; çünkü onun için çalışıp çabalanması gerekir." 
Tablo 11

Birleştiren Bir Kurum Olarak Din

\begin{tabular}{clcc}
\hline Sira & Metafor & $f$ & $\%$ \\
\hline 1 & Dünya & 2 & 0.85 \\
2 & Evren & 2 & 0.85 \\
3 & Aile & 1 & 0.43 \\
4 & Ayna & 1 & 0.43 \\
5 & Cumhuriyet & 1 & 0.43 \\
6 & Ev & 1 & 0.43 \\
7 & Kardeş & 1 & 0.43 \\
8 & Kuş & 1 & 0.43 \\
9 & Yuva & 1 & 0.43 \\
\hline
\end{tabular}

Birleştiren bir kurum olarak din kategorisinde, 11 öğrenci tarafından 9 farklı metafor üretilmiştir (Tablo 11). Bu metaforların araştırmada üretilen toplam geçerli metaforlar içerisindeki oranı \%4.68'dir. Kategoride en fazla tercih edilen metaforlar dünya ve evren metaforlarıdır. Bu kategoride öğrenciler, dinin insanları birleştiren, birbirine bağlayan, bir arada tutan yönünü gerekçe göstererek metaforlar üretmişlerdir. Öğrencilerin ürettikleri metaforlardan bazıları gerekçeleriyle birlikte aşağıda verilmiştir:

"Din aile gibidir; çünkü inananları birleştirir."

"Din ayna gibidir; hepimizi birbirimize benzetir."

"Din dünya gibidir; çünkü bütün insanları içine alır."

"Din ev gibidir; çünkü Müslümanları tek bir çatı altında toplar."

"Din evren gibidir; çünkü her şeyi içine alır."

"Din kardeş gibidir; çünkü bizi birbirimize bağlar."

"Din cumhuriyet gibidir; çünkü herkesi bir arada tutar." 
Tablo 12

Arındıran Bir Kurum Olarak Din

\begin{tabular}{cllc} 
Sira & Metafor & $\boldsymbol{f}$ & $\boldsymbol{\%}$ \\
\hline 1 & Güneş & 2 & 0.85 \\
2 & Su & 2 & 0.85 \\
3 & Abdest & 1 & 0.43 \\
4 & Akarsu & 1 & 0.43 \\
5 & Ay & 1 & 0.43 \\
6 & Iyilik kutusu & 1 & 0.43 \\
7 & Rüzgâr & 1 & 0.43 \\
\hline & Toplam & $\mathbf{9}$ & $\mathbf{3 . 8 3}$
\end{tabular}

Arındıran bir kurum olarak din kategorisinde, 9 öğrenci tarafından 7 farklı metafor üretilmiştir (Tablo 12). Bu metaforların araştırmada üretilen toplam geçerli metaforlar içerisindeki oran1 \%3.83'tür. Kategoride en fazla tercih edilen metaforlar güneş ve su metaforlarıdır. Bu kategoride öğrenciler, dinin insanların kalbini, vicdanını temizleyen, ferahlatan bir yapısının olduğunu gerekçe göstererek metaforlar üretmişlerdir. Öğrencilerin ürettikleri metaforlardan bazıları gerekçeleriyle birlikte aşağıda verilmişstir:

"Din güneş gibidir; kalbimizi aydınlatarak pırıl pırıl yapar."

"Din su gibidir; çünkü bizi temizler."

"Din abdest gibidir; çünkü insanı temizler."

"Din akarsu gibidir; çünkü aktıkça bizi durulandırır."

"Din rüzgâr gibidir; çünkü varlı̆̆lyla bizi serinletir."

"Din ay gibidir; çünkü herkesin vicdanını ve kalbini parlatır."

Tablo 13

Gelişen Bir Kurum Olarak Din

\begin{tabular}{clll}
\hline Sira & Metafor & $\boldsymbol{f}$ & $\boldsymbol{\%}$ \\
\hline 1 & Ağaç & 1 & 0.43 \\
2 & Boya & 1 & 0.43 \\
3 & Dostluk & 1 & 0.43 \\
4 & Fidan & 1 & 0.43 \\
5 & İnsan & 1 & 0.43 \\
6 & İnsan hayatı & 1 & 0.43 \\
7 & Tohum & 1 & 0.43 \\
\hline
\end{tabular}


Gelişen bir kurum olarak din kategorisinde, 7 öğrenci tarafından 7 farklı metafor üretilmiştir (Tablo 13). Bu metaforların araştırmada üretilen toplam geçerli metaforlar içerisindeki oranı \%2.98'dir. Öğrenciler bu kategoride metaforlarını üretirlerken dinin zaman içerisinde gelişip büyüyen, yayılan bir yapısının olduğunu gerekçe göstermişlerdir. Öğrencilerden bazılarının bu kategoride ürettikleri metaforlar ve gerekçeleri şöyledir:

"Din boya gibidir; çünkü yayılıp durur."

"Din fidan gibidir; çünkü zamanla büyür.”

"Din insan gibidir; çünkü her geçen gün büyür."

"Din tohum gibidir; çünkü suladıkça ektikçe çoğalır."

"Din ăgaç gibidir; çünkü gün geçtikçe büyür."

"Din insan hayatı gibidir; çünkü gün geçtikçe olgunlaşır."

"Din dostluk gibidir; çünkü paylaştıkça çoğalır."

Tablo 14

Kurallarl Olan Bir Kurum Olarak Din

\begin{tabular}{clcc}
\hline Sira & Metafor & $\boldsymbol{f}$ & $\boldsymbol{\%}$ \\
\hline 1 & Okul & 2 & 0.85 \\
2 & Anayasa & 1 & 0.43 \\
3 & Cumhuriyet & 1 & 0.43 \\
4 & Devlet & 1 & 0.43 \\
5 & Ödev & 1 & 0.43 \\
\hline & Toplam & $\mathbf{6}$ & $\mathbf{2 . 5 5}$ \\
\hline
\end{tabular}

Kuralları olan bir kurum olarak din kategorisinde, 6 öğrenci tarafından 5 farklı metafor üretilmiştir (Tablo 14). Bu metaforların araştırmada üretilen toplam geçerli metaforlar içerisindeki oran1 \%2.55'tir. Kategoride en fazla tercih edilen metafor okul metaforudur. $\mathrm{Bu}$ kategoride öğrenciler, dinin kesin, adaleti sağlayan ve uyulması gereken kurallarının olduğunu gerekçe göstererek metafor ürettikleri görülmektedir. Öğrencilerden bazılarının bu kategoride ürettikleri metaforlar ve gerekçeleri şöyledir:

"Din anayasa gibidir; çünkü her kuralı kesindir."

"Din okul gibidir; çünkü okuldaki kurallar gibi dinimizde de uymamı gereken kurallar vardır."

"Din devlet gibidir; çünkü insanların uyması gereken kuralları vardır."

"Din cumhuriyet gibidir; çünkü adaleti sağlayan kuralları vardır."

\section{Sonuç ve Tartışma}

Ortaokul öğrencilerinin din kavramına ilişkin algılarının metaforlar aracılığıyla belirlenmeye çalışıldığı bu araştırmada, öğrenciler tarafından toplam 112 farklı metafor üretilmiştir. Bu sayı din kavramının çok yönlü algılandığını göstermektedir. Üretilen metaforlar içerisinde en fazla tercih edilen metafor 1şı metaforudur. Işık metaforu 27 
öğrenci tarafından tercih edilmiş ve üretilen metaforların \%11.49'unu oluşturmuştur. Bu metaforu, sırasıyla $8 \mathrm{kez}$ üretilen ay (\%3.40) ve güneş (\%3.40) metaforları ve $7 \mathrm{kez}$ üretilen yıldız (\%3.40) ve yol (\%3.40) metaforları takip etmiştir.

Öğrencilerin din kavramını algılamalarına ilişkin ürettikleri metaforlar 11 kategori altında toplanmıştır. Bu kategorilerden rehber, yol gösterici bir kurum olarak din kategorisinde 109 öğrenci tarafından 38 farklı metafor üretilmiştir. Araştırmada en fazla metafor bu kategoride üretilmiştir. Üretilen toplam metaforların \%46.37'si bu kategoride yer almaktadır. Işık, ay, yıldız ve yol metaforları en fazla tercih edilen metaforlardır. $\mathrm{Bu}$ kategoride üretilen metaforların bazılarına değişik çalışmalarda rastlamak mümkündür. Saban'ın (2004) giriş düzeyindeki sınıf öğretmeni adaylarının öğretmen kavramına ilişkin geliştirdikleri metaforlar adlı çalışmasında, yol gösterici ve yönlendirici olarak öğretmen kategorisinde anahtar, deniz feneri, kutup yıldızı, köprü, pusula ve yol metaforları üretilmiştir. Öğretmen adaylarının öğretmen kavramına ilişkin algılarının metaforlar aracılığıyla belirlendiği başka bir çalışmada (Yılmaz, Göçen, \& Y1lmaz, 2013) yol gösterici öğretmen kategorisinde anahtar, anne, anne-baba, ay, baba, deniz feneri, fener, güneş, 1şık, lamba, pusula, rehber ve yıldız metaforları yer almıştır. Aydın'ın (2010) yaptığı çalışmada da kılavuzun ifadesi olarak coğrafya kategorisinde harita ve anahtar metaforları üretilmiştir. Bu durum, anılan kavramların çoğunlukla yol gösteren, rehberlik eden, kılavuz gibi anlamlar içeren kavramların algılanmasında metafor olarak kullanıldığını göstermektedir. Ayrıca öğretmenlik mesleği ile dinin yol gösterme, rehberlik etme özellikleri bakımından benzeştiğini de göstermektedir.

Koruyucu, kurtarıcı bir kurum olarak din kategorisinde en fazla kalkan, şemsiye ve asker gibi insanları dış etkilerden, tehlikelerden koruyan metaforlar tercih edilmiştir. Yapılan başka bir metafor çalışmasında (Meral ve diğerleri, 2016) kalkan metaforu korunmanın ifadesi olarak çevre kategorisi içerisinde yer almaktadır.

Eğiten, öğreten bir kurum olarak din kategorisinde en fazla tercih edilen metaforlar kitap, öğretmen, hayat metaforlarıdır. Saban (2004) yaptığı çalışmada kitap metaforunu, bizim çalışmamızda yapılan değerlendirmeye benzer bir değerlendirme yaparak bilgi sağlayıcı olarak öğretmen kategorisinde ele almıştır. Yılmaz ve diğerlerinin (2013) yaptığı çalışmada aile, 1şık, internet ve kitap metaforları bilgi kaynağı olan öğretmen kategorisinde yer almıştır.

Gerekli bir kurum olarak din kategorisinde öğrenciler dini, su ve güneş gibi canlı yaşamında önemli rol oynayan kavramlarla açıklamışlardır. Fidan'ın (2014) teknoloji kavramına ilişkin geliştirilen metaforlar ile ilgili çalışmasında su ve güneş metaforlarını ihtiyaç kategorisinde ve Aydın'ın (2010) su metaforunu zorunluluğun ifadesi olarak coğrafya kategorisi altında incelemesi su ve güneş metaforlarının gereklilik, zorunluluk, ihtiyaç arz eden durumlarda sıkça kullanılan metaforlar olduklarını göstermektedir.

Değerli bir kurum olarak din kategorisinde öğrenciler dini, insanların çoğunluğunun görüş birliği ile değerli kabul ettiği ve yaşamda önemli bir yeri olan kavramlara benzeterek açıklamışlardır. Bunlar kalp, altın, anne-baba, vatan gibi kavramlardir.

Sınırsız, sonsuz bir kurum olarak din kategorisinde aşk metaforu en fazla tercih edilen metafordur. Bunun yanında öğrencilerin güneş, okyanus, gökyüzü ve yüksek dağlar gibi coğrafi kavramlarla da metafor ürettikleri görülmektedir. Aydın’ın (2010) 
yaptığı çalışmada üretilen okyanus metaforu da sonsuzluğun ifadesi olarak kabul edilmiş ve sonsuzluğun ifadesi olarak coğrafya kategorisinde yer almıştır.

Yansitan, ödüllendiren bir kurum olarak din kategorisinde en fazla ağaç, ayna ve ödev metaforları üretilmiştir. Öğrencilere göre din, yapılanların (olumlu ya da olumsuz) karşılığının olduğu bir sisteme sahiptir. Meral ve diğerleri (2016) tarafından yapılan çalışmada ayna metaforunun yansıtıcılığının ifadesi olarak çevre kategorisinde ele alınması, kavramın bu anlamına metafor üretmede sıkça başvurulduğunu göstermektedir.

Birleştiren bir kurum olarak din kategorisinde öne çıkan metaforlar dünya, evren, ev, aile, yuva gibi metaforlar olmuştur. Bu kategoride öğrenciler, dinin insanları birleştirici yönüne vurgu yaparak metafor üretmişlerdir.

Arındıran bir kurum olarak din kategorisinde öğrenciler güneş, su, abdest, akarsu gibi temizleme ve arındırma özelliği olan kavramları metafor olarak kullanmışlardır.

Gelişen bir kurum olarak din kategorisinde ağaç, boya, tohum, dostluk gibi zaman içerisinde gelişen, büyüyen, etrafa yayılma özelliği olan kavramlar metafor olarak kullanılmıştır.

Kuralları olan bir kurum olarak din kategorisinde öğrenciler okul, devlet gibi kendisine bağlı olan kişiler için kuralları olan yapıları metafor olarak kullanmışlardır.

Çalışmada üretilen metaforlar dikkate alındığında öğrencilerin din algılarının olumlu yönde olduğu görülmektedir. Araştırmada öğrenciler din kavramına ilişkin olumsuz bir metafor üretmemişlerdir. Bu durumun ortaya çıkmasında öğrencilerin bulundukları eğitim kademelerinin ve yaşadıkları sosyokültürel çevrenin etkili olduğu düşünülmektedir. $\mathrm{Bu}$ durumun nedenlerinin araştırılması ise ayrı bir çalışmanın konusudur. Ayrıca yapılan bu çalışmanın başka bir bölgede veya diğer eğitim kademelerinde yenilenmesi farklı sonuçlar çıkarabilecektir.

Memişoğlu ve Tarhan (2016) Sosyal Bilgiler öğretmenlerinin kavram öğretiminde en çok zorlandıkları kavramların soyut kavramlar olduklarını, bu kavramlar arasında din kavramının da yer aldığını belirtmişlerdir. Bu nedenle din kavramının öğretiminde görsel materyallerin, duyulara hitap eden uyarıcıların kullanılması kavramın öğretimini kolaylaştıracaktır. Sosyal Bilgiler dersinde din kavramı ile bağlantılı içeriklerin sunumunda ve özellikle değerlerin öğretiminde öğrencilerin din algıları dikkate alınarak şiir, masal ve hikâye tekniği (Önder, 2013) ile metinlerin daha anlaşılır hale getirilmesi sağlanmalıdır. Bu kapsamda sunulacak içerikler belirlenirken Din Kültürü ve Ahlak Bilgisi öğretmenleriyle işbirliği yapılması faydalı olacaktır.

$\mathrm{Bu}$ çalışma, metafor temelli öğretimin Sosyal Bilgiler dersi öğretim programında yer alan kavramların ögretiminde kullanılabileceğini göstermiştir. Tünkler, Tarman ve Güven (2016) yaptıkları çalışmada metafora dayalı öğretim etkinliklerinin Vatandaşılık ve Demokrasi Eğitimi Dersi Öğretim Programında yer alan soyut kavram ve değerlerin öğretiminde etkili bir araç olduğu sonucuna ulaşmışlardır.

Kavramların içerikleri dönemden döneme ve kültürden kültüre az ya da çok farklılaşmaktadır. Sosyokültürel ve düşünsel devrimlerin yaşandığı dönemler, bir önceki dönemden köklü kopuşu imler ve bu kopuş kavramların anlamlarını tümden etkileyebilir (Aydın, 2006). Bu nedenle Akyürek'in (2003) belirttiği gibi dinin geçmiş, bugün ve gelecek boyutları göz önüne alınarak onun zengin kültürel mirası ve yorum zenginliği bir veri kaynağı olarak değerlendirilebilir. Ayrıca din dilinin özellikleri, dinin 
insan kişiliğini kuşatıcı yönü, onun günlük yaşantılarla bağı düşünülerek kavram haritaları oluşturulabilir. 


\section{Summary}

Purpose and Significance: Because of having curriculum reflecting interdisciplinary approach, lesson of Social Studies has a rich structure in terms of concepts. In curriculum of Social Studies there are 91 concepts in $4^{\text {th }}$ grade, 121 concepts in $5^{\text {th }}$ grade, 124 concepts in $6^{\text {th }}$ grade and 121 concepts in $7^{\text {th }}$ grade. One of these is religion which is an anthropological and sociological concept. The religion whose beginning is as old as humanity is one of the most substantial foundations effecting individuals and societies in every part of the history (Keskin, 2004). Having a source in almost every corner of the planet, world religions show a diversity as much as existing cultures. For this reason and it is about some subjects like God, the purpose of life and afterlife, these make it hard to define religion (Wilkinson, 2008: 14). Religion is a system of belief, prayer and morals and it is depicted as a concept connecting love to a being and all thoughts and practices as required by this faith (Keskin, 2004). Because of being an abstract concept, religion is pretty hard to be learnt and perceived by pupils. In an attempt to be understood easily, this concept should be narrated by embodying it as much as possible. In this stage it is frequently applied to embody concepts with metaphors.

Metaphor is a usage of a word in a different meaning with referring via similarity so as to express a concept, a word, a term or a fact better and more pleasant (Aydın İ.H., 2006). Metaphor is a perfect technique to teach unknown things and also is a tool whose validity was proved in the matter of keeping learnt things in mind and recalling them. With metaphors, pupils connect new information with old ones by attaching diagrams that already exists in their minds (Arslan \& Bayrakc1, 2006).

In this study, it is aimed to determine the perception of religion concepts of pupils in $6^{\text {th }}$ and $7^{\text {th }}$ grade in secondary school via metaphors and to detect under which conceptual categories they are gathered. When the literature is looked through, it is seen that there are metaphor studies about some concepts in Social Studies curriculum but there isn't any about religion concept. So in this sense, this study is very important.

Method: One of the qualitative research methods, phenomenological approach, was used in this research. The phenomenological approach focuses on understanding how people see themselves and the world around (Robson, 2015: 186). A phenomenological approach is well suited to studying affective, emotional, and often intense human experiences. (Merriam, 2013: 26). The data collected from 235 pupils attending $6^{\text {th }}$ and $7^{\text {th }}$ grades in secondary schools of Kütahya central and Altıntaş district in 2015-2016 academic year. Forms that had been prepared for this study was given out pupils for the purpose of revealing metaphors of participant pupils' perception of religion concept. Before the study, the concept of metaphor had been described to the pupils and explained with various examples. After that, it was asked pupils to complete this sentence: "Religion is like ...; because ...". It was given 25 minutes to the pupils for this activity. At the end, the forms were analyzed. The metaphors produced by the pupils analyzed by going through (1) decoding and sorting, (2) forming a sample metaphor list, (3) developing category, (4) providing validity and reliability, (5) converting to quantitative data phases (Saban, 2009). 
Results: In this study, totally 112 different metaphors was produced by pupils. This number shows that concept of religion is comprehended multi-directionally. Among produced metaphors, it is light metaphor that was preferred most. It was chosen by 27 pupils and it is \%11.49 of produced metaphors. After this one, there were moon (\%3.40), and sun (\%3.40) metaphors produced 8 times and star (\%3.40) and road (\%3.40) metaphors produced 7 times.

Metaphors that pupils produced to perceive concept of religion was collected under 11 categories. Among these, in religion as a guiding, counselling foundation category 38 different metaphors were produced by 109 pupils. It was the category that metaphors were produced most. It contains $\% 46.37$ of total produced metaphors. The most preferred metaphors are light, moon, star and road metaphors.

In the category of religion as a protective, saver foundation, 16 different metaphors were produced by 23 pupils. In this category, metaphors protecting people from external factors like shield, umbrella and soldier were chosen.

In the category of religion as an educative, instructive foundation, 11 different metaphors were produced by 19 pupils. In this category the most preferred metaphors are book, teacher and life metaphors.

In the category of religion as a necessary foundation 12 different metaphors were produced by 15 pupils. Religion was explained with concepts playing an essential role in human life such as water and sun in pupils' produced metaphors.

In the category of religion as a precious foundation 10 different metaphors were produced by 12 pupils. Pupils explained religion by likening the concepts having an important place in life and commonly accepted as essential figures. These are concepts such as heart, gold, parents and homeland.

In the category of religion as a limitless, infinite foundation 10 different metaphors were produced by 12 pupils. Metaphor of love is the most chosen metaphor in this category. It is also seen that pupils produced metaphors about geographical concepts like sun, ocean, sky and high mountains.

In the category of religion as a reflective, rewarding foundation 9 different metaphors were produced by 12 pupils. Metaphors of tree, mirror and duty were produced most in this category. According to pupils, religion has a system of response to committed (negative or positive) acts.

In the category of religion as a connective foundation 9 different metaphors were produced by 11 pupils. Prominent metaphors of this category are earth, universe, house, family and home. Pupils produced metaphors by underlining the connective aspect of religion in this category.

In the category of religion as a purifying foundation 7 different metaphors were produced by 9 pupils. Pupils used concepts having a cleaning and purifying feature like sun, ablution, river in this category.

In the category of religion as a developing foundation 7 different metaphors were produced by 7 pupils. Concepts having a feature of developing, growing and spreading over time such as tree, paint, seed and friendship were used as a metaphor in this category. 
In the category of religion as a formal foundation 5 different metaphors were produced by 6 pupils. Pupils used structures having rules for people connected to itself such as school and government as a metaphor in this category.

\section{Discussion and Conclusions:}

Having considered the metaphors produced in this study, it's seen that pupils' perception of religion is positive. In the study pupils haven't produced negative metaphors about concept of religion. Pupils' level of education and socio cultural environment are thought to be the effective reasons of this situation. The cause of this situation is a subject of different study. Besides, repeating this study in another region or for other levels of education is likely to draw different conclusions.

Various studies show that teachers face challenges in teaching abstract concepts. Concept of religion is regarded as among the hard-to-teach topics. For this reason, the use of visual materials and stimuluses appealing to the senses will simplify this concept. In the lessons of Social Studies, while teaching religious concepts, especially values, contents can made more understandable by storytelling techniques, poems and tales considering pupils' perception of religion.

Contexts of concepts vary from period to period and from culture to culture more or less. Therefore, rich cultural heritage of religion and richness of its commentary must be regarded as sources of data regarding past, current and future dimensions of it. 


\section{Kaynakça}

Akyürek, S. (2003). Din kültürü ve ahlâk bilgisi derslerinde kavram haritalarının kullanımı. Değerler Ĕ̆itimi Dergisi, 1(3), 65-85.

Alkış, S. (2012). Sosyal bilgilerde kavram öğretimi. M. Safran (Dü.) içinde, Sosyal bilgiler öğretimi (2. bask1, ss. 69-92). Ankara: Pegem Akademi.

Arslan, M. M., \& Bayrakcı, M. (2006). Metaforik düşünme ve öğrenme yaklaşımının eğitim- öğretim açısından incelenmesi. Milli Eğitim Dergisi, 171, 100-108.

Ateş, M., \& Karatepe, A. (2013). Üniversite öğrencilerinin "çevre” kavramına ilişkin algilarının metaforlar yardımıyla analizi. The Journal of Academic Social Science Studies, 6(2), 1327-1348.

Aydın, F. (2010). Ortaöğretim öğrencilerinin coğrafya kavramına ilişkin sahip oldukları metaforlar. Kuram ve Uygulamada Eğitim Bilimleri, 10(3), 1293-1322.

Aydın, F. (2013). Üniversite öğrencilerinin “çevre" kavramına ilişkin metaforik algıları. Doğu Coğrafya Dergisi, 16(26), 25-44.

Aydın, H. (2006). Sosyal bilimlerde kavram öğretimi: Eleştirel bir yaklaşım. Aralık 4, 2017 tarihinde http://turkoloji.cu.edu.tr/GENEL/hasan_aydin_kavram_ogretimi.pdf adresinden alınd 1

Aydın, İ. H. (2006). Bir felsefi metafor "yolda olmak". Dinbilimleri Akademik Araştırma Dergisi, 6(4), 9-22.

Baltacı, Ö. (2015). Evli bireylerin “aile” ve “evlilik” kavramlarına yönelik metaforik algılarının bağlanma stillerine göre değerlendirilmesi. International Journal of Eurasia Social Sciences, 6(21), 223-243.

Candan, A. S. (2004). Kavramlar. MEB Talim ve Terbiye Kurulu Başkanlığı içinde, Sosyal Bilgiler 4. -5. Sınıf Programı. Ankara: Milli Eğitim Bakanlığı.

Coşkun, M. (2010). Lise öğrencilerinin “iklim” kavramıyla ilgili metaforları (zihinsel imgeleri). Turkish Studies International Periodical For the Languages, Literature and History of Turkish or Turkic, 5(3), 919-940.

Creswell, J. W. (2013). Research design (Araştırma Deseni). (S. B. Demir, Çev.) Ankara: Eğiten Kitap Yayınları.

Çayc1, B. (2007). Kavram değiştirme metinlerinin kavram öğrenimi üzerindeki etkisinin incelenmesi. Gazi Ĕ̆itim Fakültesi Dergisi, 27(1), 87-102.

Dündar, H. (2008). Sosyal bilgilerde kavram öğretimi. Özel ögretim yöntemleriyle sosyal bilgiler ögretimi (ss. 302-334) içinde. Ankara: Pegem Akademi.

Eraslan, L. (2011). Sosyolojik metaforlar. Akademik Bakış Dergisi, 27, 1-22.

Fidan, M. (2014). Öğretmen adaylarının teknoloji ve sosyal ağ kavramlarına ilişkin metaforik algıları. The Journal of Academic Social Science Studies, 25, 483-496.

Forceville, C. (2002). The identification of target and source in pictorial metaphors. Journal of Pragmatics, 34, 1-14.

Gündüz, Ş. (2010). Giriş (dinin anlam ve değeri). Ş. Gündüz (Dü.) içinde, Yaşayan Dünya Dinleri. Ankara: Diyanet İşleri Başkanlığı Yayınları.

Güven, M. (2012). Kültürün bir unsuru olarak din. Batman Üniversitesi Yaşam Bilimleri Dergisi, 1(1), 933-948. 
Karaçam, S., \& Aydın, F. (2014). Ortaokul öğrencilerinin teknoloji kavramına ilişkin algilarının metafor analizi. Gaziantep University Journal of Social Sciences, 13(2), 545-572.

Keskin, Y. M. (2004). Din ve toplum ilişkileri üzerine bir genelleme. Dinbilimleri Akademik Araştırma Dergisi, 4(2), 7-21.

Korkmaz, F., \& Ünsal, S. (2016). Okul öncesi öğretmenlerin "teknoloji” kavramına ilişkin metaforik algılarının incelenmesi. Mustafa Kemal Üniversitesi Sosyal Bilimler Enstitüsü Dergisi, 13(35), 194-212.

MEB. (2005). Sosyal bilgiler dersi 6 ve 7. sinıflar ögretim programı ve kılavuzu. Aralık 20, 2016 tarihinde Talim ve Terbiye Kurulu Başkanlığı: http://ttkb.meb.gov.tr/www/ogretim-programlari/icerik/72 adresinden alınd1

MEB. (2017). Sosyal bilgiler dersi öğretim programı (Illkokul ve Ortaokul 4, 5, 6 ve 7. Sinıflar). Ankara. Eylül 20, $2017 \quad$ tarihinde http://mufredat.meb.gov.tr/ProgramDetay.aspx?PID=155 adresinden alınd 1

Memişoğlu, H., \& Tarhan, E. (2016). Sosyal bilgiler öğretmenlerinin kavram öğretimine ilişki görüşleri. Eğitim ve Öğretim Araştırmaları Dergisi, 5(Özel Sayı), 6-20.

Meral, E., Küçük, B., \& Gedik, F. (2016). Sosyal bilgiler öğretmen adaylarının çevre kavramına ilişkin metaforik algıları. Kastamonu Eğitim Dergisi, 24(1), 65-78.

Merriam, S. B. (2013). Qualitative research-A guide to design and implementation. (S. Turan, Çev.) Ankara: Nobel Akademik Yayıncılık.

Miles, M. B., \& Huberman, A. M. (1994). Qualitative data analysis: An expanded sourcebook (2. basım). California: SAGE Publications.

Önder, M. (2013). Sevgi, din dili ve hikayelerin çocukların din eğitimindeki yeri ve önemi. The Journal of Academic Social Science Studies, 6(3), 1285-1298.

Özkan, R., \& Taşkın, M. A. (2014). İlköğretim öğrencilerinin vatan olgusuna ilişkin algılarının belirlenmesi. Tarih Okulu Dergisi, 7(17), 889-906.

Ritchie, L. D. (2013). Metaphor. New York: Cambridge University Press.

Robson, C. (2015). Real World Research. (N. D. Şakir Çınkır, Çev.) Ankara: Anı Yayıncilik.

Saban, A. (2004). Giriş düzeyindeki sınıf öğretmeni adaylarının "öğretmen” kavramına ilişkin ileri sürdükleri metaforlar. Türk Eğitim Bilimleri Dergisi, 2(2), 131-155.

Saban, A. (2009). Öğretmen adaylarının öğrenci kavramına ilişkin sahip oldukları zihinsel imgeler. Türk Ĕ̈itim Bilimleri Dergisi, 7(2), 281-326.

Saban, A., Koçbeker, B. N., \& Saban, A. (2006). Öğretmen adaylarının öğretmen kavramına ilişkin algılarının metafor analizi yoluyla incelenmesi. Kuram ve Uygulamada Ĕ̈itim Bilimleri, 6(2), 461-522.

Sezer, E. (2003). Dilde ve edebiyatta yol metaforu. Kitap-llk Dergisi, 65, 88-92.

Solmaz, B. (1996). Dinin toplum ve kültür üzerine etkileri. Selçuk Üniversitesi İlâhiyat Fakültesi Dergisi, 6, 125-145.

Sönmez, Ö. F., \& Akıncan, N. (2013). Ortaokul öğrencilerinin "yardımseverlik" değeri ile ilgili metafor algıları. Gaziosmanpaşa Bilimsel Araştırma Dergisi(7), 105-120. 
Tünkler, V., Tarman, B., \& Güven, C. (2016). Vatandaşlık ve demokrasi eğitimi ögretim programında yer alan soyut kavramların ve değerlerin öğrencilere kazandırılmasına ilişkin metaforik bir yaklaşım. Eğitim ve Bilim, 41(185), 123-145.

$\begin{array}{llll}\text { Türk Dil Kurumu. } & \text { (2016, }\end{array}$ http://www.tdk.gov.tr/index.php?option=com_gts\&arama=gts\&guid=TDK.GTS.58 5ea9e369a9a1.06319132 adresinden alınd

Uyan-Dur, B. İ. (2016). Metafor ve ekslibris. Uluslararası Ekslibris Dergisi, 3(5), 122128.

Ünsal, V. (2013). Eski Anadolu'da teokratik devlet düzeni . Ankara: Berikan Yayınevi.

Wilkinson, P. (2008). Religions: Eyewitness companions. New York: DK Publishing.

Yapıcı, M., \& Kösterelioğlu, İ. (2016). Öğretmen adaylarının felsefe dersine ilişkin metaforlar1. Kuramsal Eğitimbilim Dergisi, 9(4), 662-677.

Yazıcı, Ö. (2013). Coğrafya öğretmenlerinin "çevre" kavramına ilişkin algıları: Bir metafor analizi çalışması. The Journal of Academic Social Science Studies, 6(5), 811-828.

Yıldırım, A., \& Şimşek, H. (2013). Sosyal bilimlerde nitel araştırma yöntemleri. Ankara: Seçkin Yayıncılık.

Yılmaz, F., Göçen, S., \& Y1lmaz, F. (2013). Öğretmen adaylarının öğretmen kavramına ilişkin algıları: Bir metaforik çalışma. Mersin Üniversitesi Eğitim Fakültesi Dergisi, 9(1), 151-164.

Yob, I. M. (2003). Thinking constructively with metaphors. Studies in Philosophy and Education, 22(2), 127-138. doi:10.1023/A:1022289113443 